Bangladesh J. Sci. Ind. Res. 41(1-2), 15-22, 2006

\title{
The Participation of Different Categories of Farmers for the Production and Utilization of Lady's Finger (Hibiscus esculentus L.)
}

\author{
M. Harunur Rashid, M. Nur-E-Elahi and M. Akhter Hossain Khan \\ RFS Division, Bangladesh Rice Research Institute, Gazipur-1701, Bangladesh
}

\begin{abstract}
A study was conducted at the Farming Systems Research and Development (FSR\&D) site of Bangladesh Rice Research Institute (BRRI) during kharif-I, 1999 to find the agronomic management followed for lady's finger cultivation by the different categories of farmers and to understand its production, consumption and disposal pattern together with its economy. Technical knowledge was provided to the farmers for growing lady's finger. Farmers grew the crop with their own management and resources. Variation was found in the date of sowing, rate of fertilizer application and number of irrigation. The highest pod yield was associated with better agronomic management that resulted higher gross margin. Lady's finger production, consumption and selling were increased from April to June with a peak in the month of June. Lady's finger consumption was highest per head in case of medium farmer and was decreased from medium farmer to marginal one. The utilization of money earned from lady's finger selling followed a dissimilar pattern in different categories of farmers. Cultivation of lady's finger might be an option for meeting the requirement of vegetable consumption, income generation and fulfilling the diversified demand of different category of farmers.
\end{abstract}

\section{Introduction}

Vegetables are very important group of crops and they constitute a major part of the diet contributing nutrients, especially vitamins, minerals and protein. They also make our diet more palatable and variable. ${ }^{1}$ In Bangladesh, daily per capita consumption of vegetable is $50 \mathrm{~g}$ compared to $432 \mathrm{~g}$ in Japan. $^{2}$
In the country, per head availability and consumption of vegetable is very low compared to daily requirement (200 g) due to their acute shortage. ${ }^{3}$ High yielding vegetables production may be answer to the potential problems of hunger and malnutrition. 
In Bangladesh $70 \%$ of the total vegetable production is produced in the winter due to suitable climatic condition for vegetable production. ${ }^{4}$ In the country there are two scarce period for vegetable supply, from April to May and September to October. ${ }^{5}$ Cultivation of high yielding lady's finger is an option to increase the supply of vegetables during April to May. Lady's finger is a major kharif vegetable, which has high nutritive value. It is a source of carbohydrate, fibre, protein, nayacin, vitamin and iron. Besides, $100 \mathrm{~g}$ edible lady's finger contains $1.2 \mathrm{k}$ cal energy. ${ }^{6}$ But, Yellow Vein Mosaic disease is a major problem for lady's finger growing in Bangladesh. A recently released lady's finger variety, BARIdheros-1 released by Bangladesh Agricultural Institute is resistant to the virus that makes lady's finger cultivation easier and profitable in Bangladesh. BARIdheros- 1 is flowered about 45 days after sowing and its pod harvest continued from 50 days after sowing to 5 months of its age. $^{6}$

Usually lady's finger is planted during the month of February and March where there is acute shortage of soil moisture which may cause delay in germination or some times complete failure of germination resulting in poor yield. ${ }^{7}$ Although lady's finger is very much popular in Bangladesh, the yield of the crop is very low, $3.11 \mathrm{t} \mathrm{ha}^{-1}{ }^{8}$ On the other hand, the yield of lady's finger varied from 11 to $15 \mathrm{t} \mathrm{ha}^{-1}$ from region to region. ${ }^{6}$ Lack of knowledge about some cultural practices has contributed to the poor yield of lady's finger. ${ }^{9}$ Besides this, lady's finger producing farmers do not follow the recommended practice of input use due to higher market price and lack of facilities. ${ }^{10}$ As farmers have not sufficient access to input use, recommended agronomic management do not sustain at farmer's level. For sustainable higher production of lady's finger, consideration of farmers' participatory management is imperative.

Lady's finger is an income generating summer vegetable. It may increase the farmers' income as well as reduce the shortage of vegetable consumption. Moreover, the cultivation of the crop helps to generate family labour employment greatly. ${ }^{10}$ Economic return from lady's finger cultivation may vary in different categories of farmers. The amount of production and earned money from lady's finger cultivation may affect the utilization pattern for family expenditure in different categories of farmers. The disposal pattern of the money earned from lady's finger cultivation may help the researchers to design their research plan for different categories of farmers. Therefore the present study was undertaken with the following objectives:

i. to find the agronomic management practices of lady's finger by different categories of farmers;

ii. to find the factors influencing the yield and economic return; 
iii. to see the production, consumption and selling pattern of produced lady's finger;

iv. to observe the prices pattern of lady's finger in the growing season;

v. to find lady's finger consumption per head by different categories of farmers;

vi. to note money utilization pattern earned from lady's finger by different categories of farmers.

\section{Materials and Methods}

The study was conducted at the Farming Systems Research and Development (FSR\&D) site of Bangladesh Rice Research Institute (BRRI), Kapasia during kharif-I 1999. The study area belongs to Modhupur Tract of Agro-ecological region 28. The variety, BARIdheros -1 was used in the study. Seeds of lady's finger (Hibiscus esculentus L.) were distributed among six farmers taking two from each category, marginal to large in the first week of February 1999. Technical knowledge was provided to the farmers for growing lady's finger. Unfortunately, one farmer of marginal category could not cultivate the crop due to lack of sufficient moisture in the soil. During the growing period of the crop, the monthly minimum and maximum air temperatures were $15.7^{\circ} \mathrm{C}$ and $32.5^{\circ} \mathrm{C}$, respectively, in February and April. A total of $8.6 \mathrm{~mm}, 325 \mathrm{~mm}, 338 \mathrm{~mm}$. and 528 $\mathrm{mm}$ rainfall were recorded in the month of April, May, June and July respectively. There was no rainfall during the months of February and March. Farmers grew this crop with their own inputs. The plot size of marginal, small-1, small-2, medium-1 and medium-2 farmers were 175, 225, 290, 500 and $250 \mathrm{~m}^{2}$ respectively. Seeds were sown by the participating farmers at different dates at 50 $\mathrm{cm}$ row spacing and $40 \mathrm{~cm}$ plant spacing. Two seeds were sown in every pit and one seedling was uprooted remaining a healthy seedling at 4-5 leaf stage. Fertilizer rates and all other management practices differed from one farmer to another. Lady's finger harvesting was started in the second week of April and continued up to fourth week of July. The other key management practices used for lady's finger cultivation are described in Table I. Data on harvesting, consumption, selling were recorded farmer wise twice a week and calculated these monthly bases. Economic analysis of lady's finger production was done based on prevailing farm gate price. Simple tabular and graphical method of analysis was carried out to arrive at results.

\section{Results and Discussion}

\section{Key agronomic management}

Table I indicated that agronomic management for lady's finger cultivation varied from farmer to farmer. Noticeable variation was found in dates of sowing, rate of fertilizer application and number of irrigation. Date of sowing started from February 26 to March 16. A marginal farmer applied only nitrogenous fertilizer at the rate of $61 \mathrm{~kg} \mathrm{~N} \mathrm{ha}^{-1}$. The 
Table I. Agronomic management for lady's finger cultivation followed by different categories of farmer

\begin{tabular}{|c|c|c|c|c|c|}
\hline $\begin{array}{l}\text { Management } \\
\text { factors }\end{array}$ & $\begin{array}{l}\text { Marginal } \\
\text { farmer }\end{array}$ & $\begin{array}{c}\text { Small } \\
\text { farmer - } 1\end{array}$ & $\begin{array}{c}\text { Small } \\
\text { farmer - } 2\end{array}$ & $\begin{array}{l}\text { Medium } \\
\text { farmer - } 1\end{array}$ & $\begin{array}{l}\text { Medium } \\
\text { farmer - } 2\end{array}$ \\
\hline Land preparation & & & & & \\
\hline a) No. of plough & 4 & 5 & 4 & 4 & 4 \\
\hline b) No. of level & 4 & 6 & 4 & 4 & 4 \\
\hline Date of sowing & March 14, 1999 & March 16, 1999 & March 7, 1999 & Feb. 26, 1999 & March 6, 1999 \\
\hline $\begin{array}{l}\text { Row x hill } \\
\text { spacing (cm) }\end{array}$ & $50 \times 40$ & $50 \times 40$ & $50 \times 40$ & $50 \times 40$ & $50 \times 40$ \\
\hline $\begin{array}{l}\text { Date of germina- } \\
\text { tion }\end{array}$ & March 19, 1999 & March 21, 1999 & March 12, 1999 & March 3, 1999 & March 11, 1999 \\
\hline $\begin{array}{l}\text { Fertilizer rate : } \\
\left(\mathrm{N}-\mathrm{P}-\mathrm{K} \mathrm{kg} \mathrm{ha}{ }^{-1}\right)^{*}\end{array}$ & $61-0-0$ & $60-18-45$ & $60-0-0$ & $51-20-38$ & $30-0-30$ \\
\hline $\begin{array}{l}\text { No of weeding } \\
\text { with date }\end{array}$ & 2, $32 \& 46$ DAS & $2,30 \& 50 \mathrm{DAS}$ & 2, $30 \& 55$ DAS & 2, $25 \& 52$ DAS & 2, $28 \& 60$ DAS \\
\hline $\begin{array}{l}\text { No. of irrigation } \\
\text { with date }\end{array}$ & - & $2,20 \& 95$ DAS & - & - & - \\
\hline
\end{tabular}

*Recommended rate of fertilizer : 69, 20 and $75 \mathrm{~kg} \mathrm{~N}, \mathrm{P}$ and $\mathrm{K} \mathrm{ha}^{-1}$, respectively.

small farmer-1 and small farmer-2 applied equal dose of nitrogen, which was $60 \mathrm{~kg}$ $\mathrm{N}^{-1}$. The small farmer- 1 also used $\mathrm{P}$ and $\mathrm{K}$ @ 18 and $45 \mathrm{~kg} \mathrm{ha}^{-1}$. The medium-1 and medium farmer-2 applied N @ 51 and 30 kg $\mathrm{N}^{-1}$; 38 and $30 \mathrm{~kg} \mathrm{~K} \mathrm{ha}{ }^{-1}$, respectively. The medium farmer-1 also used $20 \mathrm{~kg} \mathrm{P}$ ha- ${ }^{-1}$. All the participating farmers applied nitrogenous and potassium fertilizer less than recommended rate. The medium farmer-1 and small farmer- 1 used equal or close to recommended rate of phosphorus fertilizer (Table I). However, they did not follow the recommended package of fertilizers. Only small farmer-1 gave two supplemental irriga- tions in his lady's finger plot. In the production process of lady's finger, all the farmers followed the recommended row and plant spacing and the number of seedling per pit.

Yield of lady's finger in different categories of farmers

The pod yield of lady's finger varied from 6.9 to $18.9 \mathrm{t} \mathrm{ha}^{-1}$ in relation to farmer's category (Table II). The pod yield did not exceed $8 \mathrm{t}$ $\mathrm{ha}^{-1}$ except a small farmer. The highest pod yield (18.9 $\mathrm{t} \mathrm{ha}^{-1}$ ) was found in case of small farmer-1. This higher yield might be attributed to the application of close to recommended $\mathrm{P}$ and higher $\mathrm{K}$ than other farmers 
Table II. Yield and economic return of lady's finger obtained in different categories of farmers

\begin{tabular}{l|c|c|c|c}
\hline Farmer's category & Yield (t/ha) & Gross return (Tk/ha) & Total variable cost (Tk/ha) & Gross margin (Tk/ha) \\
\hline Marginal & 7.9 & 87,086 & 25,024 & 62,062 \\
Small farmer-1 & 18.9 & 188,311 & 28,015 & 160,296 \\
Small farmer-2 & 7.0 & 75,948 & 24,949 & 50,999 \\
Medium farmer-1 & 8.0 & 98,060 & 27,259 & 70,801 \\
Medium farmer-2 & 6.9 & 68,760 & 25,969 & 42,791 \\
\hline
\end{tabular}

along with nitrogen fertilizer and two supplemental irrigations (Table I). The findings were partial agreement with the results of other researchers ${ }^{11,12}$ where they stated that the recommended rate of nitrogen in combination with phosphorus and potassium gave the higher pod yield.

Economic analysis indicates that the small farmer who used the better agronomic management got the highest gross margin of Taka 1,60, 296 ha $^{-1}$. It was due to higher pod yield.

Monthly production, consumption and selling pattern of lady's finger

Figure 1 shows the monthly production, consumption and selling pattern of lady's finger of different farmers for the months of April to July. From the figures, it is observed that lady's finger harvesting continued to increase up to June and thereafter it was declined. Consumption and selling also maintained the same trend. The higher consumption and selling were associated with the higher rate of harvesting.
Per head lady's finger consumption and Value of consumed lady's finger

The number of family members of marginal and small farmers was six whereas it was 10 and 14 in medium farmer- 1 and medium farmer-2, respectively. Per head lady's finger consumption was the highest in the medium farmer- 1 and it was decreased with medium farmer-2, marginal farmer and small farmer1 (Fig. 2). It was due to consumption of other food for their daily menu. The age bar might be another cause for this variation.

\section{Prices pattern of lady's finger}

Figure 3 indicates that the price of per $\mathrm{kg}$ lady's finger was the highest in the second week of April e.g. Tk. $16.00 \mathrm{~kg}^{-1}$. The price of lady's finger was unchanged from the third week of April to second week of May and thereafter it was gradually declined.

Farmers' participatory production of lady's finger might be motivated the neighbouring 


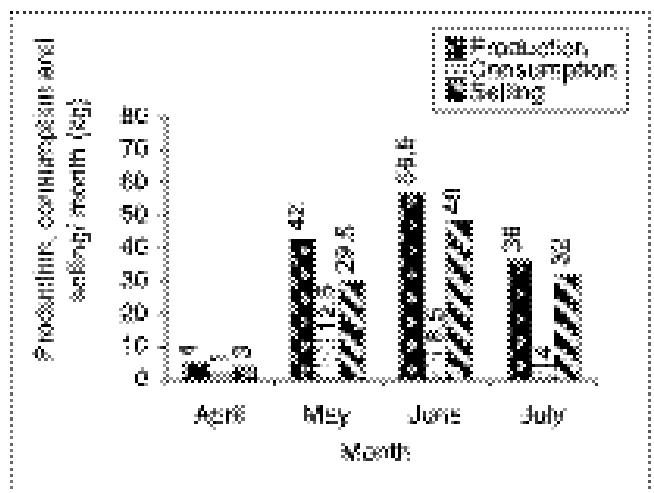

Fig. 1a Utilization pattern of okra of marginal farmer

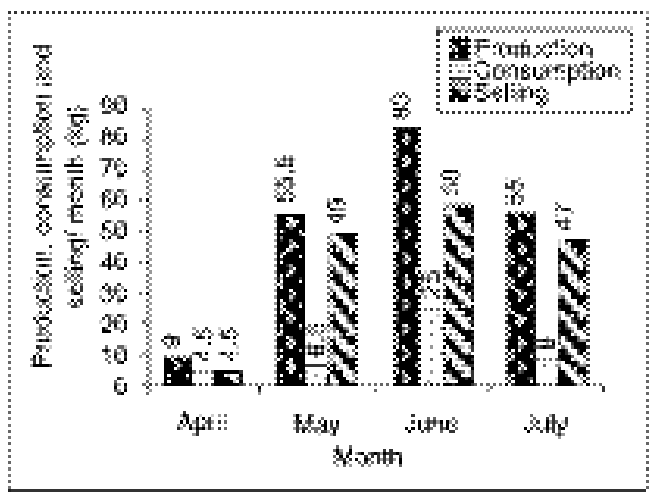

Fig. 1c Utilization pattern of okra of small farmer-2

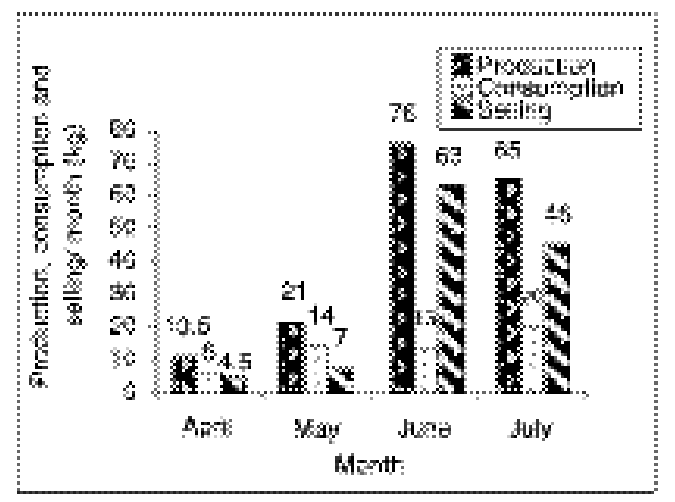

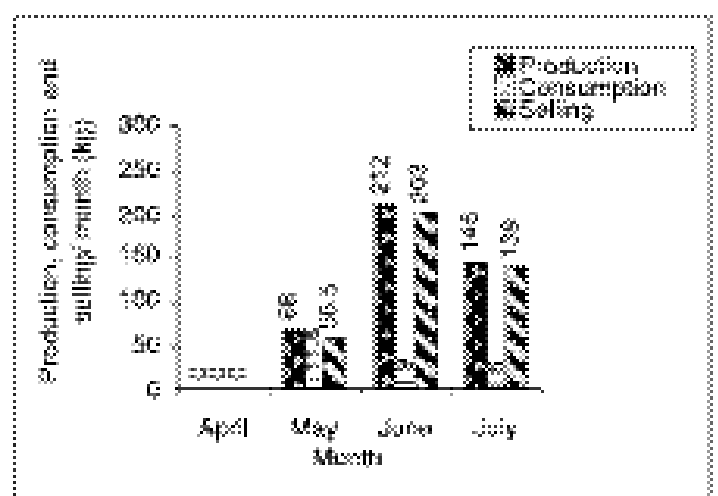

Fig. 1b Utilization pattern of okra of small farmer-1

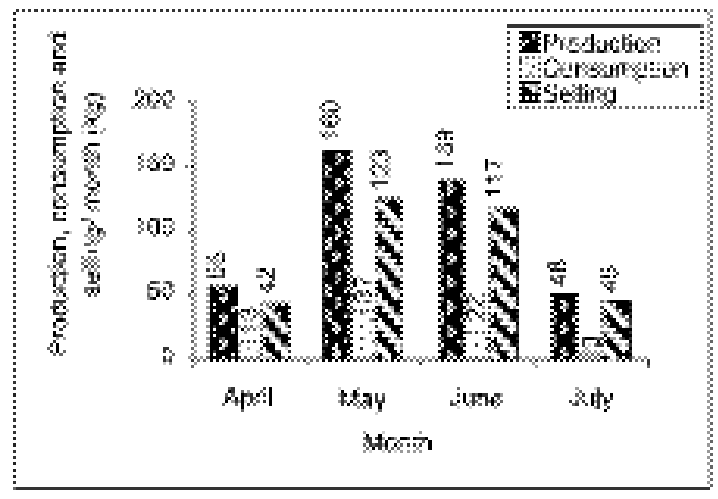

Fig. 1d Utilization pattern of okra of medium farmer-1

Fig. 1. Monthly production, consumption and selling pattern of okra in different categories of farmers

Fig. 1e Utilization pattern of okra of medium farmer-2 


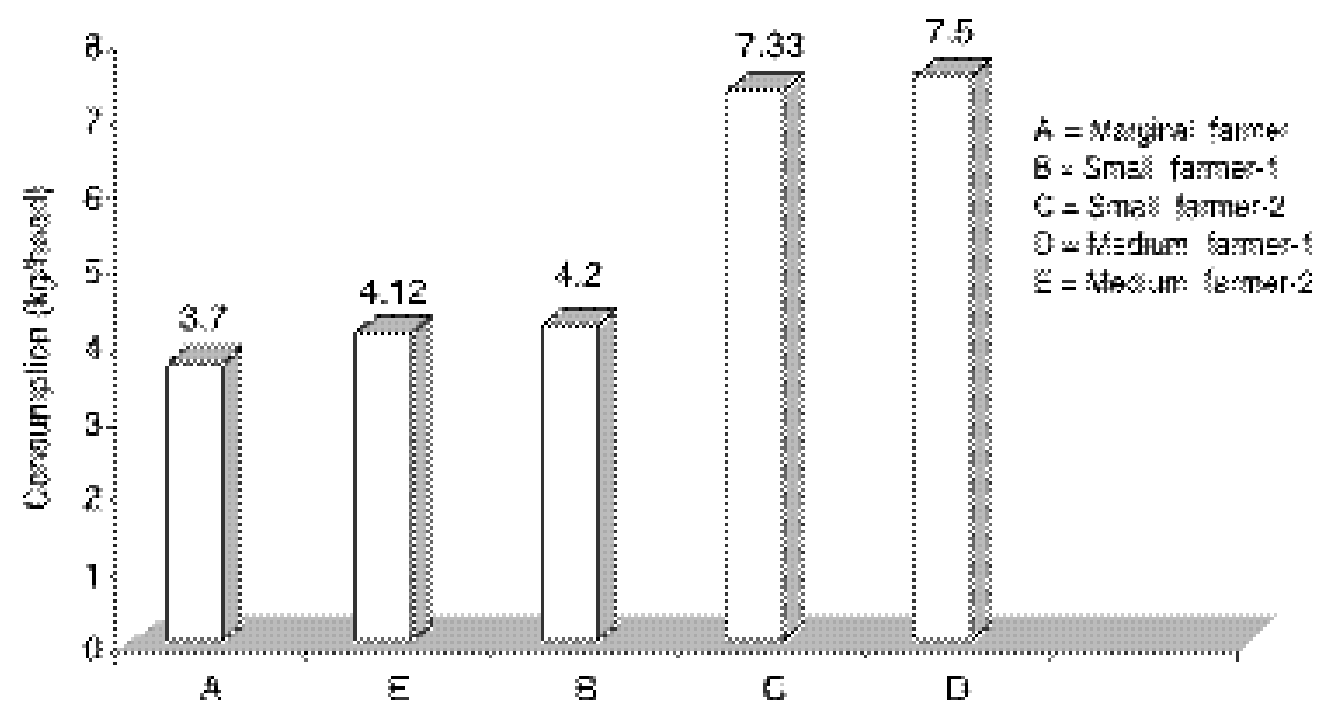

Fig. 2. Per head okra consumption pattern of the different farmer categories

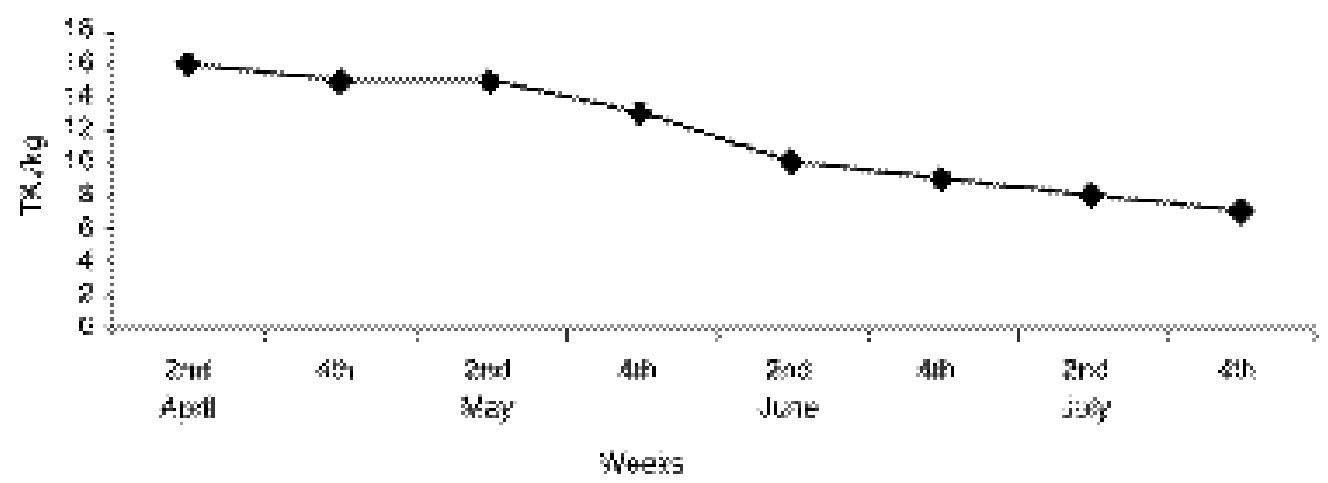

Fig. 3. Prices pattern of okra in different weeks from April to July 
farmers to grow the crop following the management at their resource level. Lady's finger cultivation might meet the requirement of vegetable consumption as well as help in income generation and fulfil the diversified demand of family.

\section{References}

1. S. C. S. Tsou. Vegetables production and marketing. Proceedings of a National Review and Planning Workshop. AVRDC/BARI/BARC: USAID ARP = II Supplement, (1992) 21-30.

2. S. S. Rekhi. Vegetable improvement and seed production in Bangladesh. Paper presented in the National seminar on Vegetable Improvement and seed Production held at Bangladesh Agricultural Research Institute, (1997). Gazipur, Bangladesh.

3. BARC (Bangladesh Agricultural Research Council). Farming Systems Agribusiness Newsletter, 1990, April-June issue. Dhaka, Bangladesh.

4. M. A. Razzaque, M. A. Sattar, M. S. Amin, M. A. Quayyum and M. S. Alam. (ed.) Hand book on Agro-technology. Second Ed. (In Bangla). Bangladesh Agricultural Research Institute, Gazipur, (2000) 313.

5. M. M. Rashid Olericulture (In Bangla), 1999. Rashid Publishing House; 94, Old D.O.H.S., Dhaka.

6. S. M. Hossain. (ed.) Modern varieties of vegetables and cultivation methods (In
Bangla), Olericulture Division, Horticulture Research Center, Bangladesh Agricultural Research Institute, Gazipur, (2000) 48-49.

7. M. G. Rasul, M. A. Sattar, M. A. Mannan and M. M. Rashid. Effect of mulching and earthing up on the performance of Mukhikachu. Bangladesh Hort. 20(1) (1992) 51-54.

8. BBS (Bangladesh Bureau of Statistics). Statistics Division, Ministry of Planning, Dhaka. Monthly statistical bulletin Bangladesh, April (2000).

9. P. K. Saha, D. K. Aditya and A. F. M. Sharfuddin. Effects of plant spacing and picking interval on the growth and yield of lady's finger cv. Pusasawani. Bangladesh Hort. 17(2) (1989) 10-14.

10. M. I. Hossain, M. S. Rahman and R. Islam. Impact study of improved technology of lady's finger cultivation. Bangladesh $J$. Agril. Res. 25(3) (2000) 529-540.

11. G. P. Chaudhari, K. G. Mahakal, A. S. Shrirame, S. U. Gondane and V. J. Kawarkhe. Performance of lady's finger varieties in relation to fertilizer application. PVK Res. J. 19 (1) (1995) 95-96.

12. A. Fayaz, M. Ishtiaq, S. Muhammad and F. Ahmad. Effect of different levels of nitrogen alone and in combination with constant doses of phophorus and potassium on growth and yield of lady's finger cv. T-13. Sorhad J. of Ag. 15(5) (1999) 405-407. 